\title{
Expanding access to rights-based family planning: Activity brief
}

The Evidence Project

Follow this and additional works at: https://knowledgecommons.popcouncil.org/departments_sbsr-rh

Part of the Demography, Population, and Ecology Commons, Family, Life Course, and Society Commons, International Public Health Commons, Maternal and Child Health Commons, and the Women's Health Commons How does access to this work benefit you? Let us know!

\section{Recommended Citation}

"Expanding access to rights-based family planning: Activity brief." Washington, DC: The Evidence Project, 2015.

This Brief is brought to you for free and open access by the Population Council. 


\section{Expanding Access to Rights-Based Family Planning}

\section{ACTIVITY BRIEF}

\section{OVERVIEW}

The human rights dimensions of family planning programs have been recognized for nearly half a century and affirmed in numerous declarations, conventions, and treaties endorsed by governments and the international community.

While discourse about respecting, protecting, and fulfilling these rights is growing, a gap persists between human rights rhetoric and integrating rights in family planning policy, programs, and practice. Governments and programs struggle with defining and operationalizing a rights-based approach to family planning. Overall, there is scant evidence on: 1) how to implement rights-based family planning (RBFP) programming, 2) how to measure rights-based programming and outcomes, and 3 ) the effect on family planning/ reproductive health outcomes of implementing rights-based family planning. Furthermore, literacy about human rights and family planning is generally low at the global, national, and sub-national levels.

Working with a range of stakeholders, the Evidence Project is conducting several activities to address these gaps. Such work is particularly timely given growing global agreement on the need to ensure access to rights-based programming while meeting ambitious goals for new family planning users.
BOX 1

\section{What is a Rights-Based Approach to Family Planning?}

A rights-based approach to family planning programs does not follow a single, prescribed set of activities. Rather it places the individual's dignity and needs at the center and includes components at the policy, service, community and individual levels that:

- Analyse family planning inequalities.

- Ensure that plans, policies and programs are grounded in a system of core rights.

- Work toward equitable service delivery, particularly among youth and marginalized populations.

- Focus on availability, accessibility, acceptability and quality of service provision.

- Empower family planning clients and stakeholders to participate and hold services accountable. ${ }^{1}$

\section{BOX 2}

\section{Human Rights and Empowerment Principles for Family Planning}

FP2020 has articulated rights and em-

powerment principles that need to be

addressed in country level family planning

programming. ${ }^{2}$ WHO put its normative

weight behind guidance and recommenda-

tions to ensure human rights are respected

when providing contraceptive information

and services. ${ }^{3}$ Together, FP2020 and WHO

list 13 rights and empowerment principles.
- Acceptability of information and services

- Accessibility of information and services

- Availability of information and services

- Quality of information and services

- Transparency and accountability
- Agency and autonomy

- Empowerment

- Equity

- Informed choice

- Informed decisionmaking

- Non-discrimination

- Voice and participation

- Privacy and confidentiality 


\section{Evidence Project Activities}

\section{1}

\section{DEFINING RIGHTS-BASED FAMILY PLANNING AND SYNTHESIZING RESOURCES}

The Evidence Project is collaborating with global partners to consistently define RBFP programming through participation in working groups and meetings. The Project also has synthesized key frameworks, tools, and principles documents to help implementers operationalize RBFP. "Rights-based Family Planning: 10 Resources to Guide Programming," pulls together resources for putting into action a rights-based approach to family planning, highlighting each resource's aims, scope and content, and how to use it.

\section{2}

\section{INCORPORATING AND OPERATIONALIZING RIGHTS-BASED APPROACHES IN COSTED IMPLEMENTATION PLANS}

The Evidence Project, together with IPPF's Sustainable Networks Project (SIFPO2), are taking part in a groundbreaking process spearheaded by the Ministry of Health and Reproductive Health Uganda (RHU) to develop an action plan for a rights-based approach in support of the country's Family Planning Costed Implementation Plan (FP CIP). Using the rights and principles articulated by FP2020 and WHO (see Box 2) and the conceptual framework for voluntary RBFP (see Hardee et al., 2014), Uganda is working to move from words in a plan to rights-based services for women, men and young people. This work is helping implementers think through what they should be doing differently in their programming by taking a rights-based approach at the policy, service, community and individual levels.

\section{3}

\section{TESTING AN INDEX TO MEASURE ADHERENCE TO RIGHTS-BASED FAMILY PLANNING}

To augment the scant evidence on RBFP, the Evidence Project, with IPPF/SIFPO2 and RHU, are undertaking research to test an index to measure adherence to RBFP principles at the service delivery level (in later iterations, the index will be adapted to the policy, community and individual levels). The study is measuring individual facilities' level of integration and implementation of RBFP - including identifying rights vulnerabilities that can be addressed through small-scale service delivery modifications. The Evidence Project is collaborating with a sister study being conducted by the Palladium Group in two states in Nigeria that is also using the RBFP Index. We hope to develop a RBFP self-assessment tool as a result of this work.

\section{4}

\section{DEFINING RIGHTS-BASED INDICATORS FOR FAMILY PLANNING PROGRAMMING AND MONITORING}

The project has produced an easy-to-use table of potential rights indicators proposed by various international groups, including FP2020, WHO, and Performance, Monitoring and Accountability 2020. For each indicator or measurement, the table shows which right it reflects, the source of the metric, and under what thematic area it might be found in a FP CIP. It is an important resource in helping countries or organizations move from rights principles in planning documents to monitoring the effects of rights-based approaches to family planning. Additionally, Evidence Project staff are contributing to WHO's Technical Advisory Group on Strengthening Family Planning's Normative Standards for Monitoring, Evaluation, and Accountability.

\section{REFERENCES}

(1) K. Hardee, Kumar, J., Newman, K., Bakamjian, L., Harris, S., Rodríguez, M. and Brown, W. 2014. “Voluntary, Human Rights-Based Family Planning: A Conceptual Framework." Studies in Family Planning, 45: 1-18. http://www.popcouncil.org/research/voluntary-human-rights-based-family-planning-a-conceptual-framework (2) “Family Planning 2020: Rights and Empowerment Principles for Family Planning.” 2014. http://ec2-54-210-230-186.compute-1.amazonaws. com/wp-content/uploads/2014/12/FP2020_Statement_of_Principles_FINAL.pdf (3) WHO. 2014." Ensuring Human Rights in the Provision of Contraceptive Information and Services: Guidance and Recommendations. Geneva: WHO. http://apps.who.int/iris/bitstream/10665/102539/1/9789241506748_eng. pdf?ua=1;\%20http://apps.who.int/iris/bitstream/10665/102543/1/WHO_RHR_14.02_eng.pdf?ua=1

USAID Evidence
The Evidence Project is led by the Population Council in partnership with INDEPTH Network, International Planned Parenthood Federation, Management Sciences for Health, PATH, Population Reference Bureau, and a University Research Network. Other partners are FHI360, Meridian Group International, Inc., and What Works Association.
The Evidence Project is made possible by the generous support of the American people through the United States Agency for International Development (USAID) under the terms of cooperative agreement no. AID-OAA-A-13-00087. The contents of this document are the sole responsibility of the Evidence Project and Population Council and do not necessarily reflect the views of USAID or the United States Government.

For more information, go to evidenceproject.popcouncil.org or contact Karen Hardee at khardee@popcouncil.org. 